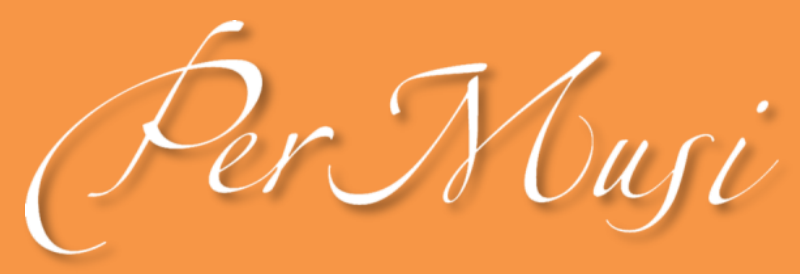

elSSN 2317-6377

\title{
Integration and opposition of Western and Japanese traditional instruments in Takemitsu's November Steps
}

\author{
Luigi Antonio Irlandini \\ https://orcid.org/0000-0001-5695-6608 \\ Universidade do Estado de Santa Catarina, Departamento de Música \\ cosmofonia.lai@gmail.com
}

SCIENTIFIC ARTICLE

Submitted date: 31 oct 2021

Final approval date: 13 dec 2021

Abstract: This article examines the combination of Japanese and Western musical traditional instruments in regards to Töru Takemitsu's November Steps. The composer brought into an yōgaku (Western music style) composition not only two traditional instruments but also their traditional music, with the intention of creating an opposition of Japanese and Western musical characteristics, and shaping them as irreconcilable forces. In order to give a fair consideration of the matter, it is necessary to know the circumstantial and historical factors that have contributed to the predicaments involved in this pioneer act of incorporation of traditional Japanese aesthetics and culture in the world of musical composition.

Keywords: November Steps; Takemitsu; Yōgaku; Japanese traditional instruments; Trans-culturalism.

TÍITULO: INTEGRAÇÃO E OPOSIÇÃO DE INSTRUMENTOS OCIDENTAIS E JAPONESES TRADICIONAIS EM NOVEMBER STEPS DE TAKEMITSU

Resumo: Este artigo examina a combinação de instrumentos musicais japoneses e ocidentais tradicionais na obra November Steps, de Tōru Takemitsu. O compositor trouxe para a composição yōgaku (música de estilo ocidental) não somente dois instrumentos japoneses tradicionais como também sua música tradicional, com a intenção de criar uma oposição entre as características musicais japonesas e ocidentais, dando-Ihes a forma de forças irreconciliáveis. Para que se possa fazer uma consideração justa deste assunto, é necessário conhecer os fatores históricos e circunstanciais que contribuíram na problemática envolvida neste ato pioneiro de incorporação da estética e cultura tradicionais do Japão no mundo da composição musical.

Palavras-chave: November Steps; Takemitsu; Yōgaku; Instrumentos japoneses tradicionais; Transculturalismo. 


\section{Integration and opposition of Western and Japanese traditional instruments in Takemitsu's November Steps}

Luigi Antonio Irlandini, Universidade do Estado de Santa Catarina, cosmofonia.lai@gmail.com

\section{Introduction}

Thirty-seven-year-old Töru Takemitsu ${ }^{1}$ (1930-1996) composed November Steps, for the short-necked lute biwa ${ }^{2}$, the end-blown bamboo flute shakuhachi, and orchestra in 1967 as a commission for the $125^{\text {th }}$ anniversary of the New York Philharmonic Orchestra. The piece was premiered in November of the same year, conducted by Seiji Osawa (b. 1935). The solo instruments were performed by two major soloists of Japanese traditional music: biwa virtuosa Kinshi Tsuruta (1911-1995) and shakuhachi master Katsuya Yokoyama (1934-2010). It is fair to say that, by now, November Steps has become a "classic", due to its innovation regarding the combination of biwa, shakuhachi and Western instruments and also because it became established as an important piece in the international New Music repertoire. Shakuhachi master Kaoru Kakizakai (b. 1959), one of Yokoyama's main pupils (shakuhachi lineage Chikunshikai), and an important authority in the contemporary world of international shakuhachi and in the subject of November Steps, states that there has been more than two hundred ${ }^{3}$ performances of November Steps by several soloists and conductors since its premiere.

With its simultaneous employment of Japanese and Western traditional instruments, November Steps has raised the issue popularly known as "East meets West" within the context of New Music composition and specifically, the issue of combining Western and Japanese traditional musical instruments in a work of contemporary art music ${ }^{4}$ of that time. In the mid-1960s, only a few Western composers, mostly from North

\footnotetext{
${ }^{11}$ This article presents partial result findings of my research project "O Círculo no Devir dos Sons: temporalidades circulares na composição musical", within the research group Processos MúsicoInstrumentais at the Music Department of the State University of Santa Catarina (UDESC).

${ }^{2}$ Non-English terms such as biwa, shakuhachi, etc., are shown in italics only when they first appear, and shown in regular font after that.

${ }^{3}$ This information comes from a personal conversation with Kaoru Kakizakai Sensei, who is my shakuhachi teacher. After he became incapacitated because of illness, Yokoyama chose Kakizakai among his students to continue performing November Steps. Kakizakai has also stated that, since then, he has performed November Steps about twenty times in Japan, Germany, Austria, Vietnam and China.

${ }^{4}$ In the term "contemporary art music" the "art music" part refers to the fact that this music was created with the intention of making art. The "contemporary" part refers to the fact that it was created in our time. At the time of the premiere of November Steps, the term "contemporary music" had stronger connotations
} 
America rather than from Europe, had shown their openness to traditional forms of philosophical and musical thought from Asia. As for Japanese composers, they were still expected by the Western music establishment to continue to be "Western-style (yögaku $\left.{ }^{5}\right)$ Japanese composers", or, in other words, the obedient and unquestioning receivers and duplicators of Western musical practices as if Japan's civilization had produced no previous classical music tradition of its own. Therefore, when November Steps was first performed in New York and subsequently recorded in an internationally distributed LP recording ${ }^{6}$, the simple presence of the biwa and shakuhachi led to the perception in the route New York-Paris that a new role for Japanese traditional instruments had been discovered in Japan, or at least by Takemitsu. It was also perceived that the shape of contemporary art music in that country might have been undergoing some independence from Western models, likely toward a "meeting of East and West". Both perceptions are not incorrect, but this statement is too simplistic to mean anything. In reality, the introduction of traditional Japanese instruments in the work of yōgaku composers had already started in the 1950s, and November Steps was not Takemitsu's first composition to employ them, neither this was a simple matter for him or by any other Japanese composer.

What follows here is an attempt to investigate in depth the problem of "East meeting West" in relation to Takemitsu's November Steps. As much as possible, this will focus the particular issue of transcultural orchestration represented by the presence of biwa and shakuhachi together with the Western orchestra in a yōgaku composition.

\section{Yōgaku composers and Japanese traditional music}

No one should write, at this point of history, the expression "East meets West", and this has been done here with the sole purpose of creating the opportunity to state clearly that one should not continue doing it. "East" and "West", or "Orient" and "Occident", are terms without a clear meaning. No one knows what they refer to exactly. Especially "East", as it does not even differentiate the Japanese from the Chinese, Indian, or Islamic civilizations, for example. "West", on its turn, includes, in principle, only one civilization, the European. However, European civilization has spread beyond the geographical boundaries of Europe and was able to install itself in North America, Australia and New Zealand"; but because Western values and culture have been worldwide disseminated, they are found today everywhere in the planet. This single fact hampers the understanding of what "West" really means in the $21^{\text {st }}$ century. Both terms (East and West) were a Western invention, and while Westerners do know what they mean by the "West", they often do not know what they mean by the "East" when they use it. Furthermore, the romantic overtones of "East meets West" has no place in the contemporary awareness that international relations have been, along the process

of avant-garde than it does today. This raises a long discussion for which there is no room here, and I suggest reading more about it in my article "A Autenticidade dos Conteúdos Antigos e Não-Ocidentais na Composição Musical dos Séculos XX e XXI" (Irlandini 2020).

${ }^{5}$ Yōgaku means Western music: Yō meaning ocean, in the sense of "beyond the ocean", and gaku meaning music (Galliano 1998, 11). I use the terms "yōgaku composers" and "yōgaku composition" with the same meaning respectively as "Western-style Japanese composers" and "Western-style Japanese composition". ${ }^{6}$ LP LSC7051 by RCA Victor, released in 1968: Seiji Osawa conducts the Toronto Symphony performing Olivier Messiaen's Turangalîla Symphonie and Takemitsu's November Steps.

${ }^{7}$ Whether or not Latin America is included in the contemporary notion of "Western civilization" remains a debated topic among historians. 
of "globalism", in their greatest majority, purely motivated by economic/financial/political dominance and imperialism. The "meeting" was not horizontal or equal, and neither had the purpose of sharing resources or solving the most common problems of the world, such as hunger or poverty, for example, in spite of the efforts of certain institutions. Art may be the realm in which this supposed meeting of civilizations has a chance to occur, but it occurs in a hidden place, the spirit of the individual artist, hints of which are shown in the artist's work. Therefore, this chance is strictly determined by particularities in the artist's life, which are caused by an array of factors, from personal, social, cultural, economic, political, etc. to poetic, aesthetic, philosophical, spiritual, and artistic, whether the art in question is music or another.

In Tōru Takemitsu's case, the meeting of Japanese and Western music as a fusion of the two musical traditions is not a straightforward matter, and probably not a fusion at all. The historical explanation of this has to do with the process of modernization/Europeanization of Japan initiated in the Meiji Era (1868-1912), which had a deep effect on the country's musical life. Western music was efficiently and dramatically transplanted by means of three main venues, according to musicologist Peter Burt, who narrates this process in detail. Once the ban on Christianity was lifted in 1873, the presence of Christian devotional music was intensified as a source of Western music in Japan. In 1872, the Ministry of Education regulated the adoption of Western pedagogical models in the public school system. This included the study of Western style singing at the elementary schools, and Western instrumental practices at the middle school. The third venue was the adoption of the European military model, which included the creation of a Western-style martial music (Burt 2001, 9). Military bands became the first musical groups to promote concerts and led to the development of other Western concert music institutions. Generations of musicians were educated in Japan as if no other music had ever been practiced there. In the course of little more than twenty years, yōgaku composers started to be active, i. e., since the 1890s (Burt 2001, 12). Their practice of composing in "Western style" was taken for granted by Westerners as something unproblematic and even natural, while yōgaku composers had to face "the central problem", as mentioned by musicologist Kenjiro Miyamoto (Burt 2001, 8), of the contrast between an imported culture and their own.

As a consequence of this transplantation of Western music into Japan, yōgaku composers in general came to discover Japanese traditional music and its instruments only later in life and with a sense of surprise. For example, this is the case of Makoto Moroi (1930-2013), whose first contact with the shakuhachi happened when he was already 34 years old. The tone color and melodic movement had for him an attractive "modernistic sense and feeling" (Moroi 1967, 9), and led him to compose his Five Pieces for Shakuhachi in the same year. Conductor Seiji Osawa, on the Foreword of Takemitsu's collected writings book Confronting Silence explains that "when I conducted the premiere performance of his November Steps (...), I encountered traditional Japanese music for the first time. In my training as a conductor I studied only Western music" (Takemitsu 1995, 9).

As for Takemitsu, he declares that "It was ten years after I began studying music that I received a strong shock from a bunraku ${ }^{8}$ performance. It was then that I became aware of Japan for the first time. In fact, I saw Japan represented as distinct from myself, and acknowledged it as entirely different" (Takemitsu apud Burt 2001, 110). It is implicit in his mentioning that the music he had begun studying, when he "began studying music", was Western. He attributed his denial of "any Japaneseness" at the beginning of his career

8 Japanese puppet theater. 
as a composer to a dislike of Japanese things due to World War II. In spite of that, Takemitsu's sensibility to music in general was victorious over his Western musical conditioning, although he states that it actually even helped his perception of traditional Japanese music:

The gidayū of the bunraku theater that I happened to hear - especially the intensity of the melodies and the rhythm of the futozao ${ }^{9}$ - made me aware of a completely different world of music. The world of sound created by the futozao was no less impressive than the world of the Western orchestra with its hundred instruments. Perhaps to me it was even richer. Such comparisons may not make much sense, but my study of Western music only strengthened and verified the extraordinary emotional reaction I experienced (Takemitsu 1995, 48).

I risk to say that, for the generations of yōgaku composers born in the 1920s and 1930s, Japanese traditional instruments were just as alien as they were to non-Japanese composers born in the same time $\operatorname{span}^{10}$, with the difference that, being from, and residing in Japan, the Japanese composers had the advantage of obtaining easy access to the parts of society in which the performance of traditional musics was alive and current. So-to-speak, it is as if they automatically had the passport to travel to these parts, if they wanted to do that. So, at the same time that these musics would seem "entirely different and distinct" from himself, Takemitsu was able to easily acculturate himself with the past of his own culture, if this is not too weird a way to put it ${ }^{11}$.

As mentioned before, the relationship between yōgaku composers and Japanese traditional music cannot be taken for granted as a natural and unproblematic matter. Each individual composer has their own unfolding of this relationship. As pointed out by Christopher Lehrich, Taketmitsu was "concerned that the

\footnotetext{
${ }^{9}$ A large kind of shamisen, a three-stringed instrument, used in bunraku.

${ }^{10}$ The accuracy or fairness of this statement is beside the point in this paper, as it may lead to other complex questions for which there is no room here. This statement implies, for example, that non-
} European individuals in general are capable of contributing to the (European) art of music composition just as much as Western composers do, a view that the latter do not necessarily or naturally share. Just in the same way, it also implies that it is possible for the modern individual, Japanese or not, and perhaps in not the exact same manner, to deeply incorporate values of a culture from the past, or the past of a culture of which they are not native, without that constituting some sort of nostalgic delusion. Regarding specifically the different types of music from Japanese traditional culture (gagaku, hōgaku, etc.), it must be noted that these are not at all "dead traditions", because they are still practiced in the country, in spite of all changes and difficulties. One would arrive at better conclusions once the discussion gets more specific and accurate about this matter, but, again, there is no room here for the subject.

${ }_{11}$ I have discussed in my article "Non-Western Musical Instruments and Contemporary Composition" (Irlandini, 2020) that, in times of intense transcultural relations, the notion of enculturation should be expanded to include what has been called "acculturation". This inclusion questions the common thought that the individuals' incorporation of elements from other cultures takes place only later in their life, and that the incorporation of the elements of their own culture is necessarily older and, for this reason, constitutes the basis of what the individuals are. Considering enculturation as a lifelong process reflects the notion that, rather than being a permanent identity, individuals change, or may change, due to the assimilation of elements from diverse cultures along their entire life. Furthermore, in the $21^{\text {st }}$ century, it is not uncommon to see Westerners that have been exposed to a foreign culture element very early in their life. 
insertion of traditional instruments into a Western orchestral context would inevitably lead to tokenism, colonialist trivialization, or even support for right-wing nihonjinron ("Japaneseness") essentialism" (Lehrich 2014, 219). It is exactly because of these concerning matters, as well as others related to modernistic aesthetic biases ${ }^{12}$, that the presence of non-Western instruments in a Western context (and yōgaku composition is a Western context) is such a neuralgic point. In order for this pain to go away, it is important to understand the meaning of Takemitsu's employment of Japanese traditional instruments in general, and in November Steps in particular.

\section{Western biases against transcultural orchestration and the work of Takemitsu}

This section discusses the general a priori stance which characterizes the reception by Westerners of a work of contemporary art music in which non-Western musical instruments are present, using for this purpose some statements by musicologist Peter Burk from his book The music of Toru Takemitsu. This stance is biased with structurally established notions that seek to reaffirm the hegemonic role of Western art music by rejecting the presence in it of non-Western contents (specifically, in this case, musical instruments).

First, however, it is important to know, at least quantitatively, the dimension of the presence of Japanese traditional instruments in Takemitsu's oeuvre. Takemitsu first employed Japanese instruments in his incidental music for cinema, starting with the 1961 NHK documentary Nihon no Monyō (Japanese Crest Patterns) (Burt 2001, 111). He continued to employ them in his film music for the rest of his life, up to, at least, Akira Kurosawa's Ran (1985) ${ }^{13}$. Takemitsu acknowledged that his film music worked as "a sort of sketch-pad for concert music", a place for the experimentation of new ideas before incorporating them in the "abstract music for the concert stage" (Takemitsu apud Burt 2001, 48). His concert art music begins incorporating Japanese instruments five years after the 1961 documentary, with Eclipse, for biwa and shakuhachi, in 1966. After the 1967 November Steps, the works including traditional instruments are limited to Distance (1972), for shō and oboe, Autumn (1973), also for biwa, shakuhachi and orchestra, Voyage (1973), for three biwa, In an Autumn Garden (1979), for gagaku ensemble, and, after a gap of thirteen years, a late piece, Ceremonial - An Autumn Ode, of 1992, for shō and orchestra. This makes a total of only seven works. Does this mean he lost his interest about composing for Japanese traditional instruments?

In his book, Peter Burk suggests that he did. However, his comments and interpretation about the composer's employment of Japanese traditional instruments in yōgaku carry a veiled devaluation or disapproval of this practice, notwithstanding the author's deep knowledge of Takemitsu's life and work. This disapproval is a common Western aesthetic value judgment connected to problems of cultural identity and cultural domination. It appears clearly in belittling statements such as "direct importation of Japanese music into a Western context", and "this form of literal and concrete incorporation of traditional Japanese music was a kind of assimilation in which, after November Steps, Takemitsu was to show almost no further interest"

\footnotetext{
${ }^{12}$ For a discussion on these biases see the paper "A Autenticidade dos Conteúdos..." (Irlandini 2020).

${ }^{13}$ Takemitsu's last film score was composed for Masahiro Shinoda's 1995 movie Sharaku. Here, the incidental music is mostly orchestral, but it is often superimposed with diegetic (within the narrative) music. A close study of this movie would reveal, for those interested in the subject, whether or not Takemitsu employed Japanese traditional instruments until his very last score of incidental film music.
} 
(Burt 2001, 111). This way of placing the subject is Burt's point of view, and hardly that of Takemitsu's. The idea that Takemitsu's musical thought was, for the rest of his life, "still strongly influenced by the aesthetics of traditional Japanese music" (Burt 2001, 111), then reaching a "profounder and, ultimately, more fruitful level than the mere appropriation of 'exotic' instruments" (Burt 2001, 112) again shows the musicologist's opinion, not Takemitsu's, that the composer arrived at a superior form of assimilation of traditional Japanese music when he did not employ the Japanese instruments. In addition, his disqualification of the presence of Japanese traditional instruments in Takemitu's film music as "anecdotal" (Burt 2001, 262) completes the underlying point being made in the book, namely, that the employment of non-Western instruments in the context of Western music has a low artistic value.

Starting with the incidental film music problem, which is also ${ }^{14}$ a "Western context", it seems to me that "anecdotal" is a harsh judgment. It does not take into account two things: 1) that the artistic value judgment of an incidental music score cannot follow the same criteria of an art music score ${ }^{15} ; 2$ ) that there is a common practice in the production of meaning in incidental film music, which is the "setting function". This may consist, for example, in the employment of a musical instrument to evoke qualities pertaining to the film's setting: the plot, characters, or circumstances in the narrative. Takemitsu wrote music for more than one hundred films, and this work "has no consistent, identifiable style" (Lehrich 2014, 219), a characteristic that echoes the stylistic variety of his concert art music, and that "where we find Takemitsu's (incidental) music mediocre, the film is likely frankly bad" (Lehrich 2014, 219). Thus, it is fair to take into consideration only his best film scores, perhaps around twenty, made for the best films of Akira Kurosawa, Masahiro Shinoda, Masaki Kobayashi, Nagisa Ōshima, Hiroshi Teshigahara and Hideo Onchi, in order to emit an opinion about his use of Japanese traditional instruments in incidental film music. These best works and films are the locus where Takemitsu was able to contribute with his highest artistic achievements in the realm of music for the cinema ${ }^{16}$. Here, we will find out that most of these movies are set in pre-Meiji Japan, mostly in the Edo period, and that the use of traditional instruments in incidental music fits the purpose of recreating the (imagined) time period in which the story takes place. Lehrich's (2014) and Deguchi's (2005) are rich and valuable discussions about the use of the nōkan in Kurosawa's Ran, for example, and still leave open to further study the subject of Takemitsu's use of traditional instruments in his incidental music.

My focus, however, is on Takemitsu's art music. This is where the employment of biwa and shakuhachi or other instruments is seen as most unjustifiable to a point of view confined to Western conventional and stereotyped categories. This point of view sees their employment, alone or together with an orchestra "in a Western concert art music context" as anecdotal and exotic, as if the composer's main intention were only to create a hybrid, especially regarding the 1960s repertoire, when these "oddities" had just started cropping up. Also, to this point of view, it seems like some kind of intrusion and impurity in the sacrosanct hall of Western art music. This is because a musical instrument is nakedly exposed in the surface of the act of

${ }^{14}$ Also or no longer, as I have discussed in the article "Non-Western Musical Instruments..." (Irlandini 2020) that today, New Music composition is no longer exclusively a Western art, and it should be recognized as a world art, the art of world new music composition.

${ }_{15}$ There is no inference that there is no art in a film music score. The differentiation between incidental film music and art music is in that the former is a piece of applied art, while the latter is a form of "abstract music (art) for the concert stage" (using Takemitsu's own words).

${ }^{16}$ Lehrich explains that Takemitsu's participation in a film production would sometimes go far beyond just composing the incidental music. 
making music: in the concert hall, the instruments are actually being played and being seen. While film music bypasses this fact (one does not see the instruments of incidental film music), concert music does not. Thus, to this day in the year 2021, the use of such instruments is still judged as a superficial thing to do, "a form of literal and concrete incorporation" or a "direct importation", something that a great artist would do well in showing "no further interest" or not any interest at all. Paradoxically, the complete musical Europeanization of an entire country (in this case, Japan) was perceived in the West as proper and natural... In one hand, Europeans think that thousands of Japanese or Chinese musicians should dedicate their lives to playing European music at the piano or the violin, as they, Europeans, do accept this fact without asking from the non-European musicians a word, apology or explanation. They take for granted that this is how things should be. In the other hand, Western musicians that dedicate their lives to playing, for example, traditional Japanese music for the shakuhachi or the koto are doomed to endlessly justify themselves, to their Western peers, with academic papers based on all kinds of sophisticated theories about transculturation or something else, in compensation for not being occupied with the piano or the violin, the music "of their own culture". When these Japanese instruments are brought into the Western ${ }^{17}$ repertoire by a composer, like in Takemitsu's case, the "appropriation of 'exotic' instruments" feels acceptable to the patronizing Western eyes and ears because those instruments were, after all, "from his own culture", or because "he was attempting a bridge between East and West", and would be tolerated as the "passing phase that it turned out to be" after all ${ }^{18}$.

\section{Characteristics of the neo-cultural musical work}

For Burt, the whole of Takemitsu's work is the history of his Japanese/Western confrontation; This starts with the composer's denial of Japaneseness, leading to a period qualified as "experimental", in which the composer opposed the two traditions, and lastly, the arrival at a mature style of "more thoughtful integration of Japanese elements within a fundamentally Western composing style". Burt complements this observation quoting Alain Poirier's words, which say 'where the two cultures are no longer separately identifiable"' (Burt 2001, 233). As described by Poirier's words, this mature style has common elements to what I have identified as a neo-cultural work of art, i. e., a work in which its formative components from different cultures have been assimilated and integrated in such a way that they are no longer necessarily separable or distinguishable, or they are free to be distinguishable without this meaning that they have not been properly integrated. Such a work is "neo-cultural"19 because it reaches a new autonomy in relation to its parent cultural inheritances. This might be well designated as a fusion or synthesis, but not only. I will explain this using Burt's description of Takemitsu's mature style, which has two points that seem off place: 1) the assumption that the use of a traditional instrument is less thoughtful than something else (I will deal with this subject in the next topic), and 2) the "fundamentally Western composing style" part. According to Burt, Takemitsu's lifelong quest as an artist was for "a kind of cultural transcendence, an internationalism of outlook" or, using the image given by Takemitsu, that he wished "to swim in an ocean that has neither West nor East, not in one that somehow links the two" (Burt 2001, 234). In such a dream ocean, the

\footnotetext{
${ }_{17}$ Yes, November Steps, as all yōgaku music is recognized by Westerners as Western style music, with the caveat that it is from Japan. I suggest it should be recognized as a piece of world new music composition. ${ }^{18}$ If the same is done by a non-Japanese composer, then... this is the theme of another paper. See the article "Non-Western Musical Instruments..." (Irlandini 2020).

19 I have borrowed the term from anthropologist Fernando Ortiz's Cuban Counterpoint: Tobacco and Sugar.
} 
"fundamentally Western" aspect of the composing style should have been transcended just as much as that of the Japanese traditional music. As an yōgaku composer aware and involved with the incorporation of elements from Japanese traditional music, Takemitsu pioneered in the field of this kind of cultural integration. He lived a transcultural experience and produced works that present various solutions to the predicaments of that experience. Today, fifty four years after the composition of November Steps, these predicaments still persist, in spite of the achievements of several other composers that deeply experienced more than one culture in their life and art, and made of their music the place for the integration, confrontation or transcendence of these cultures. Cultural integration or transcendence will always be a predicament because there is no single answer to "how it can be done successfully", but it is always aggravated by the limited thinking that sees it as a "hybridization", or the "collage" of appropriated materials such as, from the more physical to the less physical, instruments, melodies, rhythms, scales, and formative principles. Composers such as Takemitsu, who have been occupied in the creation of a musical work that is neo-cultural, have gone beyond the "fundamentally Western" aspect of composing. This is when composition must be recognized as a world art form, and no longer exclusively as a Western art form. This does not mean the loss of "regional differences toward a global culture", to use Takemitsu's words reflecting a problem he was concerned with. It means, in fact, that this world art form is not what "globalism" has become or tends to indicate: it is a world art form because it may contain cultural features that are not fundamentally nor necessarily identifiable or not identifiable, whether they are Japanese, Western, Brazilian, etc. Takemitsu's words complement this thought: "Any culture should be understood as distinctive of an area, yet changing, free from the concept of nation or institution. Will not true understanding develop only from this attitude?" (Takemitsu 1995, 112)

\section{November Steps and the incorporation of Japanese traditional instruments}

A few points need to be considered about the employment of non-Western musical instruments in a neocultural musical work in general and, specifically, Japanese traditional instruments. Therefore, these points apply directly to November Steps. I have arrived at them by means of practicing, throughout the years, to listen to music without expectations of how a musical composition "should" sound, and by the exercise of logical thinking: 1) The fact that an instrument is more evident than an abstract formative principle does not mean necessarily that the instrument is lesser than the principle. 2) The presence of the "exotic" instrument does not mean necessarily that another deeper, more abstract thing is lacking, and 3) it does not mean necessarily that the traditional instrument is playing its traditional music as some sort of quotation. 4) The fact that a musical work employs Japanese traditional instruments alone or in combination with Western instruments does not mean necessarily that it is less or more imbued with the aesthetics of Japanese traditional music than a work only for Western instruments. And 5) the fact that a work employs only Western instruments does not mean it cannot be imbued of the aesthetics of Japanese traditional music. 6) If the musical work is able to transcend its cultural formative elements, it may certainly employ or not a traditional instrument; in this case, the music played by that instrument is new: new in the same way as a son is autonomously new in relation to his father.

I will use these six points as a script to consider how November Steps integrates traditional Japanese musical elements, including some of its instruments, affirming itself as a neo-cultural musical work, and, for this 
reason, a work that should no longer be called a "Western style Japanese" (yōgaku) composition, but a piece of "world new music composition".

The first point reads: the fact that an instrument is more evident than an abstract formative principle does not mean necessarily that the instrument is lesser than the principle. This relates to the kind of thinking for which the concrete is inferior to the abstract, that the body (or matter) is inferior to the mind, as practical knowledge is to theoretical knowledge. The conception is that of an opposition between the two elements, and the superiority of the abstract over the concrete: "mind over matter"... Music composition reflects this thought whenever the highest value as knowledge is given to writing - or more precisely, écriture. For this reason, in Western music, the status of composition is higher than that of improvisation. The status of formative principles, or techniques obtained by means of écriture, is higher than those directly obtained from the musical instrument, which is physical and evident, "nakedly exposed", therefore, obvious, and, if the instrument comes from another culture, its presence constitutes a "literal, direct, concrete importation", including all the guilt that this can carry. However, this is not necessarily so, especially in Japanese traditional music, in which there is no écriture, and notation is limited to a documentary role.

Takemitsu observes, in a short article entitled "A Single Sound", published in Tōkyō in 1971, that, in the process of creating the sounds of Japanese traditional instruments, "theoretical thinking is destroyed. A single strum of the strings or even one pluck is too complex, too complete in itself to admit any theory" $(\text { Takemitsu } 1995,46)^{20}$. This characteristic of the single sound produced in such instruments in traditional music, that is, this power to "stand alone in its complexity and its integrity" is intimately bound to the silence around it, expressed by the Japanese idea of ma. Takemitsu explains $m a$ as "the unsounded part of this experience" of the single sound being autonomous. But ma "stands up to the sound"; he says: "this powerful silence is that which gives life to the sound and removes it from its position of primacy. So it is that sound, confronting the silence of $m a$, yields supremacy in the final expression". In this context, the concrete presence of the single sound is more important than any formal or theoretical aspect of music. The realization of this fundamental difference between Japanese and Western music led Takemitsu into the difficult predicaments of how to include in his music that which the biwa and shakuhachi and their traditional music had to offer. I have just stated this last phrase in a purposely pragmatic and utilitarian way, to reflect the greedy impulse of the act of appropriation, an act that never leads, as motivation, to an authentic ${ }^{21}$ incorporation of a non-Western content into a Western context.

\footnotetext{
${ }^{20}$ I am using Yoshiko Kakudo's and Glenn Glasow's English translation of "A Single Sound" from Confronting Silence Selected Writings, 1995. There are two English translations that I know of this short text Takemitsu wrote in Japanese, and they are both very different, although, in a general outline, convey more or less the same meaning. The other is, however, less clear. Because of this translation problem, I decided to keep as close as possible to only one of the translations of Takemitsu's words. Furthermore, I have decided to use many quotations from "A Single Sound" along the two paragraphs in this section. In order to avoid too much repetition of bibliographic references, I have put only one bibliographic reference at the first quotation in beginning of this paragraph, which is (Takemitsu 1995, 46). Therefore, this reference is valid for all quotations in this and the next paragraph. Two or three of them are slightly paraphrased to better fit my writing.

${ }^{21}$ For the issue of authenticity, see the article "A Autenticidade dos Conteúdos..." (Irlandini 2020).
} 
At first, Takemitsu's approach to the sounds of Japanese traditional instruments was like that of any composer motivated by a predatory instinct: he saw them as "fresh compositional material", but he "tried to recreate them, with negative results". He gradually became more conscious of these sounds, through direct contact with master performers Tsuruta and Yokoyama. After Yokoyama revealed him that the sound ideal of a shakuhachi player was "to re-create the sound of wind in a decaying bamboo grove", that "sound, in its ultimate expressiveness, being constantly refined, approaches the nothingness of that wind in the bamboo grove", the composer reached a moment of crystallization: "Japanese music is already a legacy to which no amount of reorganizing or defining will contribute a thing. It is equally foolish to make a fetish of traditional instruments. Such futile attempts contribute nothing vital to music." In opposition to a leading thought in New Music, acutely present in the 1950s, Takemitsu recognized that composing was not the same as "the solution of artificial technical problems", and that "stylistic inventions in form" should not be equated to "new musical values". Instead, his wish was "to walk in that mysterious land in which rules the recognition that sound eventually returns to nothingness in nature". To reach this poetic (in both senses of the word) ${ }^{22}$ goal he decided to use and cultivate "within his own sensitivities" both traditional Japanese and Western music "to develop different approaches to composition (...) not by resolving the contradiction between the two traditions, but by emphasizing the contradictions and confronting them". His decision to "keep the developing status of his work intact" by emphasizing those contradictions was, for him, the only way that he would not become "a keeper of the tombs of tradition". In my own words, he recognized that the only way to continue incorporating the two traditions dear to him, Japanese and Western, was to include and integrate them in a new context, that of his own music as a neo-cultural form of musical composition.

November Steps illustrates well the second point (the presence of the "exotic" instrument does not mean necessarily that another deeper, more abstract thing is lacking): the presence of biwa and shakuhachi was, in fact, for Takemitsu, the easier (and perhaps the only) way, at that point of his career, to include an abstract element of traditional Japanese music. Because of his intention to emphasize the contradictions between Japanese and Western musical temporalities, his treatment of the Japanese instruments underwent two basic procedures: 1 ) the alternation with the orchestra, and 2) the collaboration with musicians of traditional music to make an yōgaku work. Regarding the alternation with the orchestra, this is a characteristic clearly conveyed even through the very first listening of November Steps. The overall impression of the piece as a whole is that there is a consistent alternation of the orchestra with the Japanese instruments that results in the perception that they do not mix. After listening to the piece several times, one becomes aware that there are more moments than one would expect that superimpose biwa and shakuhachi, or only one of them, and the orchestra. However, the prevalent situation is that of juxtaposition, and not superimposition, of the two instrumental sources. This separation emphasizes the instrumental groups as two different sound worlds, placing them in opposition rather than integrating them, which seems coherent with Takemitsu's conclusion about how he decided to deal with the incorporation problem. Therefore, by separating biwa and shakuhachi from the orchestra, whatever their music is doing is kept as pure, and it is perceived without Western interferences. Regarding the second procedure, the collaboration with masters of traditional music allowed November Steps to receive from them, in a spontaneous way, from the contribution of their usual playing and without them having to learn or transplant technical features from Western music, more abstract features of hōgaku music such as ma timing, which has no meter nor pulsation. For this specific purpose, Takemitsu adopted, in the biwa and shakuhachi segments, a "senza tempo" proportional notation of

22 That is, "poetic" as expressed as poetry, and poetic, as part of the composer's poíesis. 
indeterminate durations with pitches written on treble clef pentagram using microtonal signs and graphic symbols for movable aspects of sound production such as different kinds of vibrato ${ }^{23}$ (Takemitsu 1967, 6). Orchestral segments, by contrast, are notated with measure bars and precise metronomic marks for tempo fluctuations, which, however, also result in a musical time without pulsation or meter. It is fair to say that, even if the coupling of biwa and shakuhachi is a $20^{\text {th }}$-century invention, as the two instruments belong to separate strata of traditional Japanese musical culture ${ }^{24}$, the biwa and shakuhachi parts in November Steps are in the same kind of musical temporality of traditional Japanese music, because this was directly introduced by the personal contribution of Tsuruta and Yokoyama from their experience as master players of traditional music.

The third point of my considerations about a neo-cultural musical work observes that the presence of a nonWestern instrument does not mean necessarily that it is playing its traditional music. Numerous examples of contemporary music employing a non-Western instrument could be brought to prove this point. A single example should suffice: Ton de Leeuw's ${ }^{25}$ Gending, of 1975, for Javanese gamelan instruments. Differently from Lou Harrison's pieces for gamelan, some of which might be seen as a direct continuation of traditional Javanese gamelan, de Leeuw's piece has its own cosmology and the Javanese instruments sound accordingly. In fact, it is most characteristic of a neo-cultural musical work that a given non-Western instrument (or, in Gending's case, an entire ensemble) is being performed according to the particular temporality expressed through the work's cosmology itself, and not of its original tradition. Here, November Steps counts as a counterexample of Gending, for the biwa and shakuhachi music sounds very much like traditional Japanese music, not only because of temporality and gesture but because traditional Japanese music in both biwa and shakuhachi already emphasize timbre (the music sounded "modernistic" to Moroi, as mentioned before), especially in the traditional genres performed by one player alone. There is, perhaps, in November Steps, an additional extra emphasis on timbre and texture that strongly connects its solo segments with the "extended techniques" aesthetics of New Music of the 1960s, while the orchestral segments are connected with the texturalism of Ligeti, Penderecki and Lutoslawski. However, as explained in relation to the second point above, the chosen performers were able to contribute with the "traditional music sound" without too much effort from the composer's part. November Steps is not actually quoting any specific piece of traditional music, but ends up generally sounding like it, except in one specific situation, which is when a soloist of the traditional instruments improvises in a certain way in the work's famous cadenza. This requires some explanation.

November Steps is formed by eleven segments inspired by the idea of danmono, which appears in several contexts of traditional Japanese music. Takemitsu mentions that "in Japanese music, danmono are the equivalent of Western variations, and the word dan means step" (Takemitsu 1995, 54). He conceived the

\footnotetext{
${ }^{23}$ With the exception of Step no. 10, which will be considered further ahead.

${ }^{24}$ The biwa is associated with gagaku (imperial court music since de 700s), the accompaniment to Buddhist mantra recitation and epic sung narratives of the Edo period in the Kyūshū island, among other contexts that do not meet with the shakuhachi. The shakuhachi, in its classical form, belongs to the komusō Zen Buddhist monks of the Fuke sect, who initiated the honkyoku repertoire, and the Edo period chamber music secular sankyoku repertoire, in which it is performed together with instruments such as the koto and shamisen.
}

${ }^{25}$ Ton de Leeuw (1926-1996) was a Dutch composer who was particularly interested in the interface between Western music and non-Western musical traditions. 
piece as a set of eleven dan (variations), and they were eleven because November, the month of the first performance, is the eleventh month of the year. However, his explanation of danmono is somewhat misleading, as the variations in the score have more to do with an idea of completely free textural variations than with the idea of a theme with variations. November Steps is completely athematic, and its variations are variations of something that cannot be identified concretely: they are variations of each other. While an analytical discussion of the form in November Steps will be saved for a next paper, it is important to mention that the term dan also means "section" in contexts such as the battle tales biwa-gundan repertoire (Ferranti, 112) and in music for koto, such as the piece Rokudan, which means "Six Dan" (Flavin, 178). November Steps' eleven dan or sections (I prefer to call them segments) are marked in the score by their number within a circle, but they hardly constitute formal sections in the "normal" understanding of morphological musical analysis: their duration vary from about five seconds to ten minutes! That said, it is Step no. 10, the piece's so called "cadenza", which comes to attention regarding the fact that there is some improvisation in it. The cadenza lasts around ten minutes of duration, and is written in graphic notation of "sequences" that may be performed in whatever order. It is, in itself, a mobile form. The biwa receives here a tablature notation, and the shakuhachi also changes to a graphic codification for general and indeterminate pitches, durations and variations of vibrato, tremolo, glissandi and intensities. Comparing existing recordings, I was able to verify that shakuhachi player Kifu Mitsuhachi's ${ }^{26}$ interpretation of Step No. 10 notation generates a performance that sounds more like the staff notated sections of the rest of the music composed by Takemitsu than Kaoru Kakizakai's ${ }^{27}$ interpretation. At some points Kakizakai's interpretation recalls very closely, for about a few tones, the famous honkyoku piece Koku (Empty Sky). The way the aleatory parts of Step no. 10 is notated shows that Takemitsu's intention was not for the shakuhachi to play a melody or any part of one; however, depending on the performer, this might happen, due to the improvisatory character of the section. As a pupil of Yokoyama, Kakizakai's intention was to follow Yokoyama's interpretation as close as possible, and, in fact, Yokoyama's interpretation also includes brief moments that recall honkyoku pieces ${ }^{28}$.

The fourth point means that the presence or absence of a Japanese traditional instrument (or any nonWestern instrument in general), alone or in combination with Western instruments, is not directly related to the work's aesthetics being deeply impregnated by the aesthetics of the Japanese traditional music of that instrument. The employment of those instruments, per se, does not make it more imbued of its original aesthetics than a work written only for Western instruments. For a musical work that has incorporated its different cultural particularities in a neo-cultural level, the presence of an actual traditional instrument is not a necessity. György Ligeti's Book One of Piano Études is a good example of music deeply in-formed by Central-African rhythmic principles which, at the same time, employs only a Western instrument (not the "king", which is the organ, but the "prince", the piano). In November Steps, biwa and shakuhachi are present. And, it is fair to say that Takemitsu shares his authorship, for an important stretch of music (Step no. 10), which takes around $50 \%$ of the work's full duration, with the two masters of traditional music. As a consequence, the work is strongly imbued with the aesthetics of Japanese traditional music thanks to the presence of traditional instruments and the active intervention of the soloists as co-authors of that section of November Steps. Regarding the strictly composed other segments of biwa and shakuhachi music, these also follow the traditional aesthetics or temporality, as mentioned in the discussion above about $m a$.

\footnotetext{
${ }^{26}$ Kifu Mitsuhachi's performance is available at https://www.youtube.com/watch?v=5ZkiPv--zYo ${ }^{27}$ Kaoru Kakizakai's interpretation is available at https://www.youtube.com/watch?v=AmmrWq34gYI ${ }^{28}$ Katsuya Yokoyama's interpretation is available at https://www.youtube.com/watch?v=wjYMzOvVXpA
} 
The fifth point reads: the fact that a work employs only Western instruments does not mean it cannot be imbued of the aesthetics of Japanese traditional music (or the aesthetics of the traditional music of some other culture). Several compositions by Hans-Joachim Koellreutter (1915-2005) may be mentioned as examples of this. Such is the case of Issei, of 1977, for voice, two clarinets, F horn, tenor trombone, mandolim, double-bass and percussion, sung in Portuguese with text by Haroldo de Campos. Koellreutter compares this piece to the introductory singing in a Nō theatrical performance, adding that it is an "essay about the expressive possibilities of a horizontal music without dimensions, so to speak, of an elementaristic character, without counterpoint nor harmony, without perspectivic depth, apparently free from the ordering action of the pulse and, therefore, acronometric" 29 (Koellreutter apud Kater 1997, 40). This point does not apply to November Steps because the work does employ the biwa and the shakuhachi.

Finally, the sixth point stated that, if the musical work is able to transcend its cultural formative elements, it may certainly employ or not a traditional instrument; in this case, the music played by that instrument is new. A musical work that has transcended its cultural formative elements is a musical temporality that is not just the sum of its parts, but a new and autonomous one. This would probably be what Takemitsu meant by "an ocean with no East and no West". Within it East and West are "hidden" and inseparably intertwined. As an early piece in this path, November Steps does not show a transcendence of its cultural formative elements, at least in regards to the work's instrumentation, because the composer meant to accentuate the difference and opposition of biwa and shakuhachi in one side and the orchestra in the other.

\section{Conclusion}

I have tried to discuss in this paper the predicaments involved in the composition of a modern Japanese composer that employs musical instruments from Japanese traditional music in the light of the idea of neoculturalism. Takemitsu's specific solution with November Steps was that of not really combining the two opposing groups of instruments: "A composer should not be occupied by such things as how one blends traditional Japanese instruments with an orchestra. Two worlds: biwa-shakuhachi and the orchestra. Through juxtaposition it is the difference between the two that should be emphasized" (Takemitsu 1995, 73). Or, in other words, the mode of integration of these instruments in November Steps is not that of simultaneous blending, but that of opposition by juxtaposition. The result of this juxtaposition in the piece's temporality, that is, in the way the musical time flows in the piece as a whole, and how it relates to the current theoretical categories of musical temporalities will be the subject of a next paper, as November Steps provides a rich reflection about this matter as a deeper level of incorporation of Japanese traditional aesthetics. For now, it is enough to stay with Takemitsu's concluding statement about the piece: "November Steps: eleven steps without any special melodic scheme... constantly swaying impulses, like those in the Noh drama" (Takemitsu 1995, 74). To be continued...

29 “'Ensaio sobre as possibilidades expressivas de uma música plana sem dimensões, por assim dizer, de caráter elementarista, sem contraponto nem harmonia, ou seja, sem profundidade perspectívica, aparentemente livre da ação ordenadora da pulsação, portanto acronométrica'." (Koellreutter apud Kater 1997, 40). 


\section{References}

Deguchi, Tomoko. 2005. Forms of Temporal Experience in the Music of Toru Takemitsu. Buffalo, N.Y.: State University of New York at Buffalo Doctor of Philosophy Dissertation.

Ferranti, Hugh. 2016. "The Kyushu biwa traditions". In The Ashgate Research Companion to Japanese Music, edited by Alison McQueen Tokita and David W. Hughes, 106-126. London: Routledge

Flavin, Philip. 2016. "Sōkyoku-jiuta: Edo-period chamber music". In The Ashgate Research Companion to Japanese Music, edited by Alison McQueen Tokita and David W. Hughes, 169-195. London: Routledge.

Galliano, Luciana. 1998. Yōgaku - Percorsi della musica giapponese nel Novecento. Venezia: Caposcarina.

Kater, Carlos. 1997. Catálogo de Obras de H.J.Koellreutter. Belo Horizonte: FEA/FAPEMIG - Fundação de Amparo à Pesquisa de Minas Gerais.

Lehrich, Christopher. 2014. "Hearing Transcendece: Distorted Iconism in Tōru Takemitsu's Film Music." Signs and Society vol. 2 no. S.1 Suplement 2014. Semiosis Research Center at Hankuk University of Foreign Studies: 215-245.

Moroi, Makoto. 1967. Five Pieces for Shakuhachi. Score. Tokyo: Ongaku no Tomu Sha Corp.

Takemitsu, Tōru. 1967. November Steps. New York, N.Y. Edition Peters. 1995. Confronting Silence. Selected Writings. Lanham, Maryland: The Scarecrow Press. 